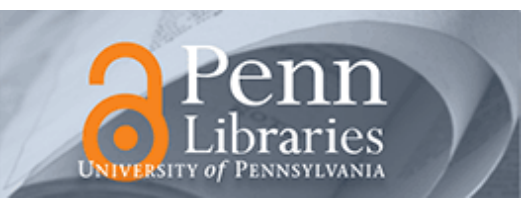

University of Pennsylvania

ScholarlyCommons

Departmental Papers (EES)

November 2002

\title{
Site factors determining epiphytic lichen distribution in a dieback- affected spruce-fir forest on Whiteface Mountain, New York: stemflow chemistry
}

\author{
Michaela Schmull \\ University of Göttingen \\ Markus Hauck \\ University of Göttingen \\ David R. Vann \\ University of Pennsylvania, drvann@sas.upenn.edu \\ Arthur H. Johnson \\ University of Pennsylvania, ahj@sas.upenn.edu \\ Michael Runge \\ University of Göttingen
}

Follow this and additional works at: https://repository.upenn.edu/ees_papers

\section{Recommended Citation}

Schmull, M., Hauck, M., Vann, D. R., Johnson, A. H., \& Runge, M. (2002). Site factors determining epiphytic lichen distribution in a dieback-affected spruce-fir forest on Whiteface Mountain, New York: stemflow chemistry. Retrieved from https://repository.upenn.edu/ees_papers/1

Copyright NRC Research Press. Published in Canadian Journal of Botany, Volume 80, Number 11, November 2002, pages 1131-1140.

Publisher URL: http://pubs.nrc-cnrc.gc.ca

This paper is posted at ScholarlyCommons. https://repository.upenn.edu/ees_papers/1

For more information, please contact repository@pobox.upenn.edu. 


\title{
Site factors determining epiphytic lichen distribution in a dieback-affected spruce-fir forest on Whiteface Mountain, New York: stemflow chemistry
}

\begin{abstract}
Epiphytic lichen diversity in a dieback-affected forest of red spruce (Picea rubens Sarg.) and balsam fir (Abies balsamea (L.) Mill.) on Whiteface Mountain, New York, U.S.A., was higher on dead compared with living trees and on fir compared with spruce. Diversity differed more between living and dead spruce than between living and dead fir. Cover of all lichen species that occurred on more than $50 \%$ of the sample trees, except for two species, decreased with increasing mean concentration of $\mathrm{NO}_{3}{ }^{-}$in stemflow. Concentrations of $\mathrm{NO}_{3}{ }^{-}$were higher on living spruce compared with dead spruce and with living and dead fir. The negative correlations between lichen cover and $\mathrm{NO}_{3}{ }^{-}$concentration may reflect either a decrease of lichen abundance caused by toxic effects of higher $\mathrm{NO}_{3}{ }^{-}$concentrations or a removal of $\mathrm{NO}_{3}{ }^{-}$from stemflow by epiphytic lichens. Experimental exposure of Hypogymnia physodes to $\mathrm{NaNO}_{3}$ reduced chlorophyll concentrations. This result, together with estimations of lichen and needle biomass, indicates that a dependence of lichen cover on $\mathrm{NO}_{3}{ }^{-}$concentrations in stemflow may be the cause for the negative correlations. The sulphur concentration in stemflow did not affect lichen abundance on Whiteface Mountain. The manganese concentration in stemflow may have an effect on single species.
\end{abstract}

\section{Keywords}

forest dieback, manganese, nitrate assimilation, nitrate toxicity, precipitation chemistry, sulphur

\section{Comments}

Copyright NRC Research Press. Published in Canadian Journal of Botany, Volume 80, Number 11, November 2002, pages 1131-1140.

Publisher URL: http://pubs.nrc-cnrc.gc.ca 


\title{
Site factors determining epiphytic lichen distribution in a dieback-affected spruce-fir forest on Whiteface Mountain, New York: stemflow chemistry
}

\author{
Michaela Schmull, Markus Hauck, David R. Vann, Arthur H. Johnson, and \\ Michael Runge
}

\begin{abstract}
Epiphytic lichen diversity in a dieback-affected forest of red spruce (Picea rubens Sarg.) and balsam fir (Abies balsamea (L.) Mill.) on Whiteface Mountain, New York, U.S.A., was higher on dead compared with living trees and on fir compared with spruce. Diversity differed more between living and dead spruce than between living and dead fir. Cover of all lichen species that occurred on more than $50 \%$ of the sample trees, except for two species, decreased with increasing mean concentration of $\mathrm{NO}_{3}{ }^{-}$in stemflow. Concentrations of $\mathrm{NO}_{3}^{-}$were higher on living spruce compared with dead spruce and with living and dead fir. The negative correlations between lichen cover and $\mathrm{NO}_{3}{ }^{-} \mathrm{concen}-$ tration may reflect either a decrease of lichen abundance caused by toxic effects of higher $\mathrm{NO}_{3}{ }^{-}$concentrations or a removal of $\mathrm{NO}_{3}^{-}$from stemflow by epiphytic lichens. Experimental exposure of Hypogymnia physodes to $\mathrm{NaNO}_{3}$ reduced chlorophyll concentrations. This result, together with estimations of lichen and needle biomass, indicates that a dependence of lichen cover on $\mathrm{NO}_{3}{ }^{-}$concentrations in stemflow may be the cause for the negative correlations. The sulphur concentration in stemflow did not affect lichen abundance on Whiteface Mountain. The manganese concentration in stemflow may have an effect on single species.
\end{abstract}

Key words: forest dieback, manganese, nitrate assimilation, nitrate toxicity, precipitation chemistry, sulphur.

Résumé : Dans une forêt d'épinette (Picea rubens Sarg.) et de sapin (Abies balsamea (L.) Mill.) de la Whiteface Mountain, New York, E.U., affectée par un dépérissement, la diversité des lichens épiphytes est plus importante sur les arbres morts que sur les arbres vivants, et sur le sapin que sur l'épinette. La diversité est plus marquée entre les épinettes vivantes et mortes qu'entre les sapins vivants et morts. La couverture par l'ensemble des espèces de lichen qui se retrouvent sur de $50 \%$ des arbres échantillonnés, sauf pour deux espèces, diminue avec l'augmentation moyenne de la teneur en $\mathrm{NO}_{3}{ }^{-}$dans le lessivat de l'arbre. Les teneurs en $\mathrm{NO}_{3}{ }^{-}$- sont plus élevées sur l'épinette vivante que sur l'épinette morte, et sur le sapin vivant que sur le sapin mort. Les corrélations négatives entre la couverture lichénique et la teneur en $\mathrm{NO}_{3}^{-}$pourraient refléter soit une diminution de l'abondance des lichens causée par les effets toxiques des hautes teneurs en $\mathrm{NO}_{3}{ }^{-}$ou soit une élimination $\mathrm{du} \mathrm{NO}_{3}{ }^{-} \mathrm{du}$ lessivat de l'arbre par les lichens épiphytes. Une exposition expérimentale de l'Hypogymnia physodes au $\mathrm{NaNO}_{3}$ réduit les teneurs en chlorophylle. Ce résultat, pris en compte avec des estimations des biomasses des lichens et des aiguilles, indique que la dépendance de la couverture lichénique sur les teneurs en $\mathrm{NO}_{3}{ }^{-}$dans le lessivat de l'arbre pourrait être la cause des corrélations négatives. La teneur en soufre dans le lessivat de l'arbre n'affecte pas l'abondance des lichens sur la Whiteface Mountain. La teneur en manganèse dans le lessivat de l'arbre pourrait avoir un effet sur une seule espèce.

Mots clés : dépérissement forestier, manganèse, assimilation des nitrates, toxicité des nitrates, chimie des précipitations, soufre.

[Traduit par la Rédaction]

Received 1 March 2002. Published on the NRC Research Press Web site at http://canjbot.nrc.ca on 5 November 2002.

M. Schmull, M. Hauck, ${ }^{1}$ and M. Runge. Albrecht von Haller Institute of Plant Sciences, University of Göttingen, Untere Karspüle 2, D-37073 Göttingen, Germany. D. Vann and A. Johnson. Department of Earth and Environmental Science, University of Pennsylvania, Philadelphia, PA 19104-6316, U.S.A.

${ }^{1}$ Corresponding author (e-mail: mhauck@gwdg.de).

\section{Introduction}

Pollutant-caused forest dieback is frequently accompanied by an increase in epiphytic lichen diversity in montane stands of Picea abies (L.) Karst. and Abies alba in central Europe (Gliemeroth 1990; Hauck and Runge 1999). In montane spruce stands of the Harz Mountains, northern Germany, Hauck and Runge (2002) and Hesse (2002) attributed this to the chemical composition of stemflow, especially to its $\mathrm{S}$ content. Cover of pollution-sensitive lichen species, to which many of the species belonged that grew more frequently in dieback-affected than in healthy sites, increased 
with decreasing mean $\mathrm{S}$ concentration of stemflow. Hauck and Runge (2002) found lower mean concentrations of S, $\mathrm{H}^{+}, \mathrm{K}, \mathrm{Fe}, \mathrm{Mn}$, and $\mathrm{Al}$ in a dieback-affected stand than in a healthy one. Hesse (2002) measured lower concentrations of $\mathrm{S}, \mathrm{H}^{+}, \mathrm{NH}_{4}{ }^{+}, \mathrm{NO}_{3}{ }^{-}$, and $\mathrm{PO}_{4}{ }^{3-}$ on damaged compared with healthy trees in a dieback-affected stand. These differences between healthy and dieback-affected spruce trees were attributed to decreasing crown surfaces with increasing needle loss. Element content of incident precipitation, atmospheric interception, and leaching of substances from the canopy determine the chemical composition of stemflow. The impact of the two latter processes decreases with decreasing crown surface. Thus, the pollutant load in the microsites of the epiphytes on trunk surfaces was lower on damaged trees than on healthy ones, although the same pollutants caused the decline of the respective trees. In addition to stemflow, the element content of bark can have an effect on epiphytic lichen diversity in dieback-affected spruce stands (Hauck et al. 2001).

In eastern North America, pollutant-caused damages in montane stands of red spruce (Picea rubens Sarg.) became apparent in the 1960s. Sulphur-containing acidic precipitation was held responsible for increases of frost injury and for growth reductions due to denaturation of proteins, membrane damage, inhibition of photosynthesis, and leaching of cations (Eagar and Adams 1993). The relationships between epiphytic lichen diversity and forest dieback in North America have not been studied. Therefore, we conducted a project in a montane spruce-fir forest of the Adirondacks, upstate New York, to clarify how pollutant-caused forest dieback affects epiphytic lichen diversity in a forest ecosystem of eastern North America. The objective was to test the hypotheses that, first, epiphytic lichen diversity is, as in Europe, higher on damaged spruce trees than on healthy ones and, second, this is influenced by stemflow chemistry. As Picea rubens is usually intermixed with balsam fir (Abies balsamea (L.) Mill.), which is not affected by pollutant-caused dieback (Johnson 1987), we further compared epiphytic lichen diversity and stemflow chemistry between these two tree species.

During our field measurements presented below, the $\mathrm{NO}_{3}{ }^{-}$ content of stemflow turned out to be of particular interest as possibly influencing lichen diversity. Hence, we carried out experimental studies of effects of $\mathrm{NO}_{3}{ }^{-}$solutions on a selected lichen species, Hypogymnia physodes. Concentrations of chlorophyllous pigments were measured to detect possible effects on the photobiont, whereas the ergosterol content was analyzed to detect effects on the mycobiont. Scanning electron microscopy (SEM) was employed to study possible structural changes in Hypogymnia physodes.

\section{Materials and methods}

\section{Study site}

Field studies were carried out on Whiteface Mountain in the Adirondacks, Essex Co., New York, U.S.A. The sample plot was located on the northwestern slope of Mt. Esther, which is part of Whiteface Mountain, at an elevation of $1100 \mathrm{~m}\left(44^{\circ} 23^{\prime} 23^{\prime \prime} \mathrm{N}, 73^{\circ} 53^{\prime} 76^{\prime \prime} \mathrm{W}\right)$. The plot was the location of numerous forest dieback studies, particularly in the 1980s (Johnson 1987). The tree layer consisted of Picea rubens, Abies balsamea, and paper birch (Betula papyrifera
Marsh.). Timber was probably never harvested on the plot. Precambrian anorthosite is the underlying bedrock on Whiteface Mountain overlain by a veneer of locally derived glacial till. Soils in the area of the sample plots are mostly Typic Cryorthods (Johnson et al. 1994). At 603 m, yearly precipitation is $1100 \mathrm{~mm}$ (National Atmospheric Deposition Program, unpublished data), annual mean temperature is $6.2^{\circ} \mathrm{C}$, and the prevailing winds are westerly. Average length of the growing season is less than 105 days (Atmospheric Sciences Research Center, unpublished data).

\section{Selection of sample trees}

A $100 \times 100 \mathrm{~m}$ sample plot was set up and spruce and fir trees with a minimum diameter at breast height of $15 \mathrm{~cm}$ and minimum height of $5 \mathrm{~m}$ were numbered. Thirty-seven trees each of living and dead spruce and of living and dead fir (the latter deriving from natural mortality) were randomly selected out of this collective for vegetation sampling; 37 was the number of available living spruce trees in the plot. Ten trees of each type (living spruce, dead spruce, living fir, dead fir) were selected out of the 37 trees for stemflow sampling.

\section{Vegetation mapping}

On all sample trees, epiphytic lichen vegetation was recorded from a standard aspect (west) and height (100$200 \mathrm{~cm}$ above the ground) to be consistent with other studies of our group (Hauck et al. 2001). This segment of the bark surface was divided into two plots, data of which were mathematically combined after field work, to obtain plots of manageable size for vegetation mapping. On the trees selected for stemflow sampling, lichen vegetation on the entire trunk from 0 to $200 \mathrm{~cm}$ was mapped (on eight plots in the aspects northwest, northeast, southwest, and southeast at heights of 0-100 and 100-200 cm above the ground). Cover of all lichen species was estimated as a percentage. Samples were qualitatively analyzed for lichen compounds by thinlayer chromatography if required for identification (Culberson and Ammann 1979). Nomenclature is based on Esslinger and Egan (1995). Lepraria jackii, which is not included in Esslinger and Egan (1995), refers to Tønsberg (1992).

\section{Sampling and chemical analysis of stemflow and incident precipitation}

Stemflow was collected with circular gutters of polyurethane and polythene tanks (Hauck and Runge 1999). Incident precipitation was collected in six replicates in $1-\mathrm{L}$ polythene bottles with attached Büchner funnels with a collecting surface of $78.5 \mathrm{~cm}^{2}$ mounted $1 \mathrm{~m}$ above the ground near Whiteface Mountain toll road. Samplers were emptied weekly from June to September in 1999 (for 15 weeks) and in 2000 (for 16 weeks). One of the living fir trees was destroyed by Hurricane Floyd in fall 1999 and could not be sampled in 2000. Rainwater was filtered with ash-free filters (Blue Ribbon Filters, Schleicher \& Schuell, Dassel, Germany). Volume, $\mathrm{pH}$ (digital $\mathrm{pH} /$ millivolt meter 611; Orion Research, Beverly, Mass.), and conductivity (conductivity resistance meter 34; YSI, Yellow Springs, Ohio) were measured immediately after sampling. After adding a drop of $300 \mu \mathrm{M}$ phenylmercuric acetate for preservation, samples were stored at $4^{\circ} \mathrm{C}$ until further analysis. Concentrations of 
$\mathrm{P}, \mathrm{S}, \mathrm{K}, \mathrm{Na}, \mathrm{Ca}, \mathrm{Mg}, \mathrm{Fe}, \mathrm{Mn}, \mathrm{Al}, \mathrm{Zn}$, and $\mathrm{Cu}$ were determined with an inductively coupled plasma atomic emission spectrophotometer (ICP-AES; Plasma 400; Perkin Elmer, Wellesley, Mass.). $\mathrm{NH}_{4}{ }^{+}$and $\mathrm{NO}_{3}{ }^{-}$were analyzed colorimetrically with an autoanalyzer (Alpkem 240; Alpkem, College Station, Tex.), whereby $\mathrm{NO}_{3}{ }^{-}$was reduced to $\mathrm{NO}_{2}^{-}$in a $\mathrm{Cd}-\mathrm{Cu}$ column. After reaction with sulphanilamide, $\mathrm{NO}_{2}^{-}$was measured in an azo dye with $\mathrm{N}$ (1-naphthyl)ethylenediamine dihydrochloride. $\mathrm{NH}_{4}{ }^{+}$was determined in a complex with indophenol blue.

\section{Incubation of Hypogymnia physodes in $\mathrm{NO}_{3}^{-}$solutions}

Hypogymnia physodes was studied in experiments for testing whether the correlation found between its cover and $\mathrm{NO}_{3}^{-}$concentrations in stemflow could be causal. Hypogymnia physodes was selected because it frequently grows both in our research plots in New York and in Germany and because it was previously used as a model organism. Thalli were sampled from Picea abies in a low-polluted area of northern Germany (Lüneburger Heide) and incubated on moist filter paper in Petri dishes for 7 days at $80 \%$ relative humidity, a day temperature (for $13 \mathrm{~h}$ daily) of $13^{\circ} \mathrm{C}$ during a photon flux of $30 \mu \mathrm{mol} \cdot \mathrm{m}^{-2} \cdot \mathrm{s}^{-1}$, and a night temperature of $10^{\circ} \mathrm{C}$. Ten replicates each were shaken twice a day for $1 \mathrm{~h}$ in $60 \mathrm{~mL}$ of each of $0,100 \mu \mathrm{M}, 1 \mathrm{mM}$, and $10 \mathrm{mM}$ $\mathrm{NaNO}_{3}$ at $\mathrm{pH}$ 4. The concentration of $100 \mu \mathrm{M}$ corresponded to the maximum concentration found in stemflow on Whiteface Mountain, $1 \mathrm{mM}$ corresponded to the maximum concentration in our German study sites, and $10 \mathrm{mM}$ is an excess concentration. $\mathrm{pH} 4$ corresponded to the mean $\mathrm{pH}$ of stemflow on Whiteface Mountain. A further control was run at $\mathrm{pH} 6$ to test whether the low $\mathrm{pH}$ of the stemflow had an effect on Hypogymnia physodes. Each replicate consisted of five thalli placed in a separate Petri dish.

\section{Analysis of chlorophyllous pigments}

Subsequent to the last incubation, three round thallus pieces of $0.26 \mathrm{~cm}^{2}$ were cut from each replicate with a borer, weighed in a water-saturated condition, and incubated with $3 \mathrm{~mL}$ of $\mathrm{N}, \mathrm{N}$-dimethyl formamide for $24 \mathrm{~h}$ at $4{ }^{\circ} \mathrm{C}$ (Moran 1982). The absorbance of the extracts was determined with a Shimadzu photometer (UV-160) at $\lambda=603,625,647$, and $664 \mathrm{~nm}$. The content of chlorophyll $a$ (Chl $a$ ) and chlorophyll $b(\mathrm{Chl} b)$ was calculated according to the following equations, which are particularly suitable for low concentration ranges (Moran 1982): Chl $a(\mathrm{ppm})=12.81 A_{664}-$ $2.16 A_{647}-1.44 A_{625}-4.91 A_{603} ; \mathrm{Chl} b(\mathrm{ppm})=-4.93 A_{664}-$ $26.01 A_{647}+3.74 A_{625}-15.55 A_{603}$. For phaeophytin measurements, the solutions were subsequently acidified with three droplets $(0.12 \mathrm{~mL})$ of $\mathrm{HCl}$ and thoroughly stirred to convert the chlorophylls quantitatively into their corresponding phaeophytins. The absorbance of the solutions was measured at $\lambda=654$ and $666 \mathrm{~nm}$. Content of phaeophytin $a$ (Phaeo $a$ ) and phaeophytin $b$ (Phaeo $b$ ) in the extracts was calculated according to the following equations: Phaeo $a^{\prime}(\mathrm{ppm})=$ $23.91 A_{666}-7.22 A_{654} ;$ Phaeo $b^{\prime}(\mathrm{ppm})=-16.38 A_{666}+$ $37.41 A_{654}$. The phaeophytin content before adding $\mathrm{HCl}$ was calculated as follows: Phaeo $a(\mathrm{ppm})=$ Phaeo $a^{\prime}(\mathrm{ppm})-\mathrm{Chl}$ $a(\mathrm{ppm})$; Phaeo $b(\mathrm{ppm})=$ Phaeo $b^{\prime}(\mathrm{ppm})-$ Chl $b(\mathrm{ppm})$ (Moran 1982). The coefficients in the equations for calculating Phaeo $a^{\prime}$ and Phaeo $b^{\prime}$ are not corrected for the loss of
$\mathrm{Mg}$ during phaeophytin formation from chlorophyll molecules so that the concentrations of Chl $a$ and $\mathrm{Chl} b$ have to be subtracted from those of Phaeo $a^{\prime}$ and Phaeo $b^{\prime}$ without converting parts per million into a molar specification before. A direct measurement of net Phaeo $a$ and Phaeo $b$ without acidifying the extracts is not possible, as the chlorophylls would interfere with the determination of the phaeophytin content (Moran 1982).

\section{Analysis of ergosterol content}

One hundred milligrams dry weight of each replicate (from the $\mathrm{NO}_{3}{ }^{-}$experiment) was homogenized, freeze-dried, hydrolyzed for $2 \mathrm{~h}$ with $6 \mathrm{~mL}$ of $10 \% \mathrm{KOH}$ and $900 \mu \mathrm{M} 2,6-$ di-tert-butyl- $p$-cresol at $60^{\circ} \mathrm{C}$, and centrifuged for $5 \mathrm{~min}$ at $1000 \mathrm{rpm}$. Four millilitres of the cooled supernatant was removed and $2 \mathrm{~mL}$ of each of $n$-hexane and deionized water was added. Samples were shaken for $5 \mathrm{~min}$ and centrifuged. One millilitre of the organic phase was transferred into vials and ablated in a vacuum chamber. The residue was liquefied in $300 \mu \mathrm{L}$ of methanol and frozen until analysis with highperformance liquid chromatography (Hewlett-Packard 1090; Hewlett-Packard, Palo Alto, Calif.) with a LiChrospher 100 column (Merck, Darmstadt, Germany).

\section{SEM studies}

Pieces of Hypogymnia physodes thalli of all treatments of the $\mathrm{NO}_{3}{ }^{-}$experiment were rapidly frozen in a 2:1 mixture of propane and isopentane cooled with liquid nitrogen to $-196^{\circ} \mathrm{C}$, freeze-dried at $-45^{\circ} \mathrm{C}$ for 3 days, and stored at $20^{\circ} \mathrm{C}$ in a desiccator over silica gel. The freeze-dried material was mounted on specimen holders, gold-coated, and examined with an SEM 515 (Philips, Eindhoven, Netherlands) operating at $20 \mathrm{kV}$. Cross sections of the thalli including the upper cortex, the algal layer, and the medulla and soredia were scanned for structural differences among thalli exposed to the different $\mathrm{NO}_{3}{ }^{-}$treatments.

\section{Statistics}

Significant differences between normally distributed data (Shapiro-Wilk test) were tested with Duncan's multiple range test; otherwise, the Mann-Whitney $U$ test was used. When more than two means were compared with the $U$ test, the probability level was corrected according to Bonferoni. Taking up the cover of lichen species versus element concentrations resulted in curvilinear relationships. Multiple linear regression analysis was used if cover of one lichen species was correlated with more than one element concentration. Before analysis, variables were $\ln$ transformed. For every $n$ (total of independent variables in the model), the multiple correlation coefficient $(R)$ was calculated for all possible combinations; $R$ was adjusted for the number of variables in the model. The model with the highest $R$ (for each $n$ ) is given in the Results section. Statistical significance was tested by calculating $F$ values. Conductivity was not considered in multiple regression analysis, as it does not directly influence lichen abundance. Spearman's rank correlation coefficients $\left(r_{\mathrm{s}}\right)$ were calculated for intercorrelation between parameters in stemflow. Statistical analyses were computed with SAS 6.04 software (SAS Institute Inc., Cary, N.C.), except for nonlinear regression (see Table 4), where Xact 4.01 (SciLab GmbH, Hamburg, Germany) was used. 


\section{Results}

\section{Epiphytic lichen vegetation}

In terms of cover, Arthonia caesia was the most dominant lichen species on living and dead spruce as well as on living fir with mean cover values of nearly $20 \%$ (Table 1). On dead fir, Hypogymnia physodes had the highest mean cover (>10\%) and Arthonia caesia the second highest. The latter inhabited $75 \%$ and the former $97 \%$ of the sample trees. Other frequent species were Lepraria jackii (on $93 \%$ of the sample trees), Imshaugia aleurites (82\%), Flavopunctelia soredica (80\%), Platismatia glauca (72\%), Lecidea nylanderi (70\%), Mycoblastus sanguinarius (56\%), Cladonia coniocraea (54\%), and Pseudevernia cladonia (53\%).

A total of 47 lichen species were recorded from the sample trees; 35 of them were found on living spruce, 40 on dead spruce, 39 on living fir, and 38 on dead fir. Eleven species occurred on Picea rubens with significantly higher mean cover on dead trees than on living ones (Table 1). On Abies balsamea, only three lichen species had a higher mean cover on dead compared with living trees. Lecidea nylanderi on spruce and Imshaugia aleurites on fir were the only species with higher mean cover on living versus dead trees. Twelve lichen species occurred with higher cover on living fir than on living spruce, whereas only Hypocenomyce friesii and Hypocenomyce scalaris were found with higher cover on living spruce compared with living fir. Cover of 10 species was higher on dead fir than on dead spruce, whereas cover of five species was higher on dead spruce versus dead fir.

\section{Amount and chemical composition of stemflow and incident precipitation}

Concentrations of $\mathrm{S}, \mathrm{Na}, \mathrm{Fe}$, and $\mathrm{H}^{+}$as well as conductivity were lower in stemflow of dead spruce trees than of living ones in both sampling periods (Table 2). Lower stemflow concentrations of $\mathrm{NO}_{3}{ }^{-}$and $\mathrm{Al}$ on dead spruce were statistically significant in 1999 only. On dead fir, concentrations of $\mathrm{S}, \mathrm{K}, \mathrm{Na}, \mathrm{Fe}, \mathrm{Mn}, \mathrm{Al}, \mathrm{Cu}$, and $\mathrm{H}^{+}$as well as conductivity were lower compared with living fir. Concentrations of $\mathrm{NO}_{3}{ }^{-}$were higher on living spruce than on living fir, whereas concentrations of $\mathrm{S}, \mathrm{K}, \mathrm{Na}, \mathrm{Fe}, \mathrm{Al}$, and $\mathrm{Cu}$ as well as conductivity were (at least in one sampling period) higher on living fir compared with living spruce. On both living and dead trees, stemflow $\mathrm{pH}$ was lower on Picea rubens than on Abies balsamea. Concentrations of most elements in incident precipitation differed between the sampling periods (Table 3 ).

\section{Correlation between the cover of epiphytic lichen species and the element content of stemflow}

The cover of 15 lichen species decreased with increasing mean $\mathrm{NO}_{3}{ }^{-}$concentration in the stemflow of the phorophyte (Table 4). Except for Arthonia caesia and Cladonia coniocraea, all species that occurred on more than $50 \%$ of the sample trees belonged to this group. For Cladonia squamosa, Evernia mesomorpha, Lepraria jackii, and Parmelia saxatilis, correlations were statistically significant in only one measuring period, but identical trends occurred in the other. In the case of Alectoria sarmentosa, Bryoria fuscescens, Cladonia pyxidata s.l., Evernia mesomorpha, Imshaugia aleurites, Lecidea nylanderi, and Pseudevernia cladonia, $\mathrm{NO}_{3}{ }^{-}$concentration was the only parameter that was correlated with cover. In other species, cover was also correlated with $\mathrm{Ca}, \mathrm{Mn}$, and (or) S. Most lichen species without significant correlations between cover and element concentrations in stemflow were rare species with a mean cover of less than $1 \%$.

Multiple regression analysis was carried out for species, the cover of which correlated with more than one element concentration in stemflow. In cases where correlations were found with $\mathrm{NO}_{3}{ }^{-}$and $\mathrm{Ca}$ concentrations, correlation coefficients were higher for $\mathrm{NO}_{3}{ }^{-}$than for $\mathrm{Ca}$. In multiple regression analysis, the correlation coefficient found with $\mathrm{NO}_{3}{ }^{-}$ content was not (Flavopunctelia soredica) or slightly increased (Hypogymnia physodes, Usnea sp.) when the $\mathrm{Ca}$ concentration was additionally considered (Table 5). The $\mathrm{NO}_{3}{ }^{-}$concentrations in stemflow were not intercorrelated with the concentrations of $\mathrm{Ca}$ or of any other element included in the multiple regression analysis (i.e., $\mathrm{S}, \mathrm{Mg}, \mathrm{Mn}$ ). In two cases (i.e., Mycoblastus sanguinarius and Parmelia saxatilis), where concentrations of each of $\mathrm{NO}_{3}{ }^{-}$and $\mathrm{Mn}$ exhibited significant correlations with lichen cover, Mn was most closely correlated with cover, and $\mathrm{NO}_{3}^{-}$(as well as $\mathrm{Mg}$ ) only slightly increased the correlation coefficient. The $\mathrm{S}$ content of stemflow did not contribute to a higher correlation coefficient in the multivariate model with Parmelia saxatilis. With Platismatia glauca, the Mn concentration slightly increased the correlation coefficient found for the $\mathrm{NO}_{3}{ }^{-}$concentration alone. Multiple regression for Cladonia coniocraea and Micarea prasina revealed that no other variables considerably increased the correlation coefficient found with the $\mathrm{S}$ content alone.

\section{$\mathrm{NO}_{3}{ }^{-}$sensitivity of Hypogymnia physodes}

Exposure of Hypogymnia physodes to $\mathrm{NO}_{3}{ }^{-}$solutions reduced the content of Chl $a$ and Chl $b$ as well as of Phaeo $a$ at $\mathrm{a} \mathrm{NO}_{3}{ }^{-}$concentration of $100 \mu \mathrm{M}$ and above (Table 6). The content of Phaeo $b$ was significantly reduced in the 1 and $10 \mathrm{mM}$ assays but not at $100 \mu \mathrm{M} \mathrm{NO}_{3}{ }^{-}$. The controls at $\mathrm{pH} 4$ and 6 differed neither in their chlorophyll nor in their phaeophytin content. The ergosterol content was not altered by any $\mathrm{NO}_{3}{ }^{-}$treatment (Table 6). No structural changes in Hypogymnia physodes thalli of any treatment could be observed by SEM (data not included). The cortex structure, the medulla, as well as fungal hyphae and photobiont cells in the algal layer and in soredia remained unaltered.

\section{Discussion}

Incident precipitation and stemflow differed from those in previous studies of forest dieback and epiphytic lichens in Germany by lower concentrations of $\mathrm{S}$ and $\mathrm{NO}_{3}^{-}$(Gliemeroth 1990; Hauck and Runge 2002; Hesse 2002). The lower S deposition with stemflow explains why significant correlations of $\mathrm{S}$ concentration in stemflow were only found with cover of Cladonia coniocraea, Micarea prasina, and Parmelia saxatilis, whereas in the Harz Mountains, Hauck and Runge (2002) and Hesse (2002) concluded from strong correlations with the most frequent lichen species that inorganic $S$ significantly affected the small-scale distribution of epiphytic li- 
Table 1. Cover of epiphytic lichen species on Picea rubens and Abies balsamea on Whiteface Mountain, New York.

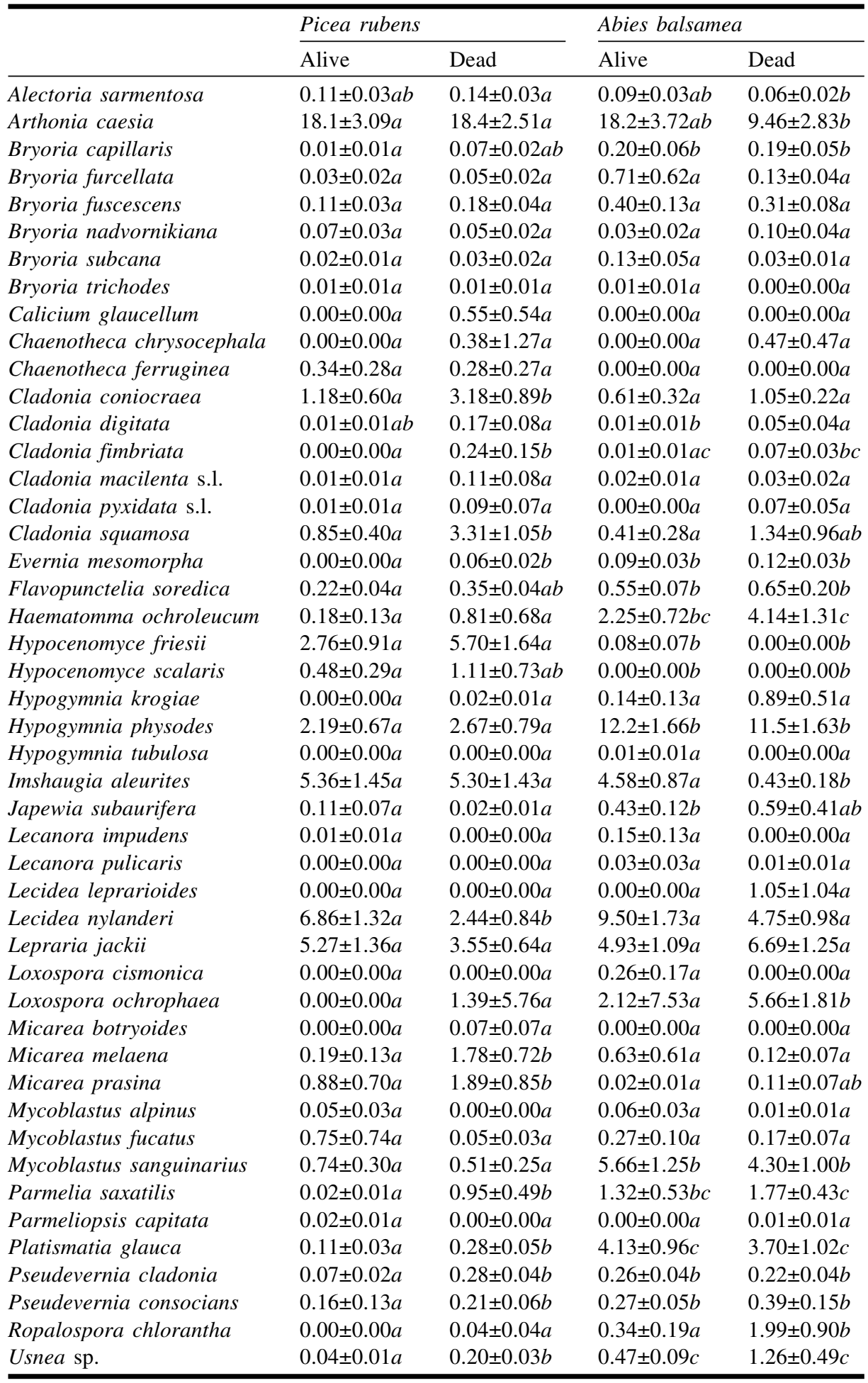

Note: Data are arithmetic means \pm SE. Within a row, means sharing a common letter do not differ significantly ( $U$ test, $p \leq 0.05$, Bonferoni-corrected).

chens on Picea abies. Experiments showed that $\mathrm{SO}_{4}{ }^{2-}$ applied in acidic solution in concentration ranges such as found in the stemflow from the Harz Mountains is capable of causing damage to lichen thalli (Hallingbäck and Kellner 1992; Piervittori et al. 1997). Lechowicz (1982) incubated Cladina stellaris for $15 \mathrm{~min}$ with simulated acid rain containing $100 \mu \mathrm{M} \mathrm{SO}_{4}{ }^{2-}$ at $\mathrm{pH} 4$ and found a reduced photosynthetic capacity. However, when Lechowicz (1982) treated Cladina stellaris with $6 \mu \mathrm{M} \mathrm{SO}_{4}{ }^{2-}$, which is in the concentration range found in the stemflow on Whiteface Mountain, no effect was 
Table 2. Amounts and element content of stemflow on Picea rubens and Abies balsamea.

\begin{tabular}{|c|c|c|c|c|c|}
\hline & \multirow[b]{2}{*}{ Year } & \multicolumn{2}{|l|}{ Picea rubens } & \multicolumn{2}{|c|}{ Abies balsamea } \\
\hline & & Alive & Dead & Alive & Dead \\
\hline \multirow{2}{*}{$\mathrm{NH}_{4}^{+}\left(\mu \mathrm{mol} \cdot \mathrm{L}^{-1}\right)$} & 1999 & $103 \pm 14 a$ & $101 \pm 12 a$ & $111 \pm 11 a$ & $135 \pm 28 a$ \\
\hline & 2000 & $60.5 \pm 3.9 a$ & $60.3 \pm 4.4 a$ & $64.3 \pm 3.7 a$ & $62.4 \pm 3.21 a$ \\
\hline \multirow[t]{2}{*}{$\mathrm{NO}_{3}^{-}\left(\mu \mathrm{mol} \cdot \mathrm{L}^{-1}\right)$} & 1999 & $15.8 \pm 4.2 a$ & $5.40 \pm 0.65 b$ & $2.26 \pm 0.41 b$ & $3.24 \pm 0.42 b$ \\
\hline & 2000 & $0.76 \pm 0.36$ & $0.24 \pm 0.07 b$ & $0.15 \pm 0.06 b$ & $0.21 \pm 0.05 a b$ \\
\hline \multirow[t]{2}{*}{$\mathrm{P}\left(\mu \mathrm{mol} \cdot \mathrm{L}^{-1}\right)$} & 1999 & $6.04 \pm 0.35 a$ & $8.42 \pm 1.34 a b$ & $9.35 \pm 0.89 a b$ & $12.0 \pm 2.3 b$ \\
\hline & 2000 & $18.9 \pm 0.3 a$ & $19.7 \pm 0.5 a$ & $20.3 \pm 0.8 a$ & $20.1 \pm 0.5 a$ \\
\hline \multirow[t]{2}{*}{$\mathrm{S}\left(\mu \mathrm{mol} \cdot \mathrm{L}^{-1}\right)$} & 1999 & $18.0 \pm 6.9 a$ & $11.6 \pm 2.5 b$ & $28.6 \pm 2.4 c$ & $11.4 \pm 0.8 b$ \\
\hline & 2000 & $13.3 \pm 2.8 a$ & $7.70 \pm 2.57 b$ & $16.6 \pm 1.5 c$ & $5.93 \pm 0.93 b$ \\
\hline \multirow[t]{2}{*}{$\mathrm{K}\left(\mu \mathrm{mol} \cdot \mathrm{L}^{-1}\right)$} & 1999 & $116 \pm 12 a$ & $178 \pm 46 a b$ & $357 \pm 39 c$ & $240 \pm 37 b$ \\
\hline & 2000 & $88.8 \pm 7.9 a$ & $131 \pm 26 a$ & $237 \pm 25 b$ & $151 \pm 31 a$ \\
\hline \multirow[t]{2}{*}{$\mathrm{Na}\left(\mu \mathrm{mol} \cdot \mathrm{L}^{-1}\right)$} & 1999 & $38.4 \pm 1.7 a$ & $30.8 \pm 1.0 b$ & $51.1 \pm 3.0 c$ & $30.5 \pm 6.3 b$ \\
\hline & 2000 & $28.0 \pm 0.8 a$ & $21.0 \pm 0.5 b$ & $30.3 \pm 1.5 a$ & $20.2 \pm 0.7 b$ \\
\hline \multirow[t]{2}{*}{$\mathrm{Ca}\left(\mu \mathrm{mol} \cdot \mathrm{L}^{-1}\right)$} & 1999 & $108 \pm 13 a$ & $106 \pm 13 a$ & $98.3 \pm 7.2 a$ & $88.9 \pm 10.3 a$ \\
\hline & 2000 & $75.9 \pm 6.8 a b$ & $99.2 \pm 20.3 a$ & $63.9 \pm 6.4 a b$ & $53.0 \pm 10.4 b$ \\
\hline \multirow[t]{2}{*}{$\mathrm{Mg}\left(\mu \mathrm{mol} \cdot \mathrm{L}^{-1}\right)$} & 1999 & $27.2 \pm 3.9 a$ & $25.2 \pm 2.7 a$ & $33.4 \pm 3.4 a$ & $31.7 \pm 10.7 a$ \\
\hline & 2000 & $17.7 \pm 1.8 a$ & $22.0 \pm 3.5 a$ & $22.0 \pm 3.7 a$ & $17.9 \pm 3.5 a$ \\
\hline \multirow[t]{2}{*}{$\mathrm{Fe}\left(\mu \mathrm{mol} \cdot \mathrm{L}^{-1}\right)$} & 1999 & $1.42 \pm 0.14 a$ & $0.71 \pm 0.05 b$ & $1.72 \pm 0.14 c$ & $0.65 \pm 0.05 b$ \\
\hline & 2000 & $1.68 \pm 0.07 a$ & $1.06 \pm 0.07 b$ & $1.76 \pm 0.14 a$ & $0.91 \pm 0.05 b$ \\
\hline \multirow[t]{2}{*}{$\operatorname{Mn}\left(\mu \mathrm{mol} \cdot \mathrm{L}^{-1}\right)$} & 1999 & $13.6 \pm 1.9 a b$ & $9.99 \pm 1.08 a$ & $18.3 \pm 2.5 b$ & $9.49 \pm 2.31 a$ \\
\hline & 2000 & $10.2 \pm 1.3 a$ & $9.63 \pm 1.89 a b$ & $12.5 \pm 2.9 a$ & $4.28 \pm 1.47 b$ \\
\hline \multirow[t]{2}{*}{$\mathrm{Al}\left(\mu \mathrm{mol} \cdot \mathrm{L}^{-1}\right)$} & 1999 & $8.16 \pm 0.37 a$ & $6.79 \pm 0.17 b$ & $10.6 \pm 0.5 c$ & $6.16 \pm 0.15 b$ \\
\hline & 2000 & $7.05 \pm 0.16 a$ & $6.45 \pm 0.22 a$ & $8.83 \pm 0.41 b$ & $5.62 \pm 0.19 c$ \\
\hline \multirow[t]{2}{*}{$\mathrm{Zn}\left(\mu \mathrm{mol} \cdot \mathrm{L}^{-1}\right)$} & 1999 & $0.92 \pm 0.22 a$ & $0.64 \pm 0.07 a$ & $0.78 \pm 0.07 a$ & $0.62 \pm 0.06 a$ \\
\hline & 2000 & $0.91 \pm 0.09 a$ & $1.01 \pm 0.14 a$ & $0.79 \pm 0.07 a$ & $0.72 \pm 0.07 a$ \\
\hline \multirow[t]{2}{*}{$\mathrm{Cu}\left(\mu \mathrm{mol} \cdot \mathrm{L}^{-1}\right)$} & 1999 & $0.37 \pm 0.01 a$ & $0.36 \pm 0.01 a$ & $0.43 \pm 0.03 b$ & $0.35 \pm 0.01 a$ \\
\hline & 2000 & $0.68 \pm 0.01 a$ & $0.72 \pm 0.02 b$ & $0.81 \pm 0.01 c$ & $0.72 \pm 0.01 b$ \\
\hline \multirow[t]{2}{*}{$\mathrm{pH}$} & 1999 & $3.74 \pm 0.03 a$ & $4.17 \pm 0.03 b$ & $3.83 \pm 0.03 c$ & $4.35 \pm 0.04 d$ \\
\hline & 2000 & $3.83 \pm 0.03 a$ & $4.18 \pm 0.04 b$ & $3.85 \pm 0.04 a$ & $4.24 \pm 0.05 c$ \\
\hline \multirow[t]{2}{*}{ Conductivity $\left(\mu \mathrm{S} \cdot \mathrm{cm}^{-1}\right)$} & 1999 & $112 \pm 10 a$ & $74.0 \pm 4.7 b$ & $139 \pm 10 c$ & $72.3 \pm 3.8 b$ \\
\hline & 2000 & $90.2 \pm 4.7 a$ & $63.7 \pm 17.8 b$ & $107 \pm 10 a$ & $53.4 \pm 3.9 b$ \\
\hline \multirow[t]{2}{*}{ Stemflow (L/tree per week) } & 1999 & $1.4 \pm 0.2 a$ & $1.1 \pm 0.1 a b$ & $1.1 \pm 0.2 a b$ & $0.8 \pm 0.2 b$ \\
\hline & 2000 & $1.7 \pm 0.3 a$ & $1.3 \pm 0.2 a b$ & $1.2 \pm 0.3 a b$ & $0.6 \pm 0.2 b$ \\
\hline
\end{tabular}

\begin{abstract}
Note: Data are arithmetic means \pm SE calculated from means of every sample tree over the entire measuring period. Measuring periods were from June to September in 1999 (15 weeks) and 2000 (16 weeks). Statistics: Duncan's multiple range test, $p \leq 0.05$, $\mathrm{df}=36$. Within a row, means sharing a common letter do not differ significantly.
\end{abstract}

observed. Multiple regression (Table 5) suggests that in the case of Parmelia saxatilis, the correlation between cover and $S$ concentration in stemflow could be due to intercorrelation with Mn content in stemflow (1999: $r_{\mathrm{s}}(\mathrm{S}, \mathrm{Mn})=0.83, p \leq$ $\left.0.001 ; 2000: r_{\mathrm{s}}=0.72, p \leq 0.001\right)$. For Cladonia coniocraea and Micarea prasina, the correlations found between cover and $\mathrm{S}$ concentrations in stemflow cannot be attributed to any intercorrelation with another element concentration in stemflow. However, it is implausible that the abundance of these species was determined by the low $\mathrm{S}$ concentrations in the stemflow on Whiteface Mountain, as they can tolerate higher $\mathrm{S}$ concentrations in other areas including the Harz Mountains (Hauck and Runge 2002). On Long Island, New York, Cladonia coniocraea was found to be the most pollution-tolerant epiphyte (Brodo 1966). Although S did not affect lichen vegetation on Whiteface Mountain, its concentration was, as in the Harz Mountains, lower in the stemflow of dead trees than in that of living ones, probably because of the lower intercepting surface of the former.

Numerous negative correlations were found between li- chen cover and $\mathrm{NO}_{3}{ }^{-}$concentration of stemflow. Correlation of low $\mathrm{NO}_{3}{ }^{-}$concentrations with high $\mathrm{pH}$ values suggests that $\mathrm{NO}_{3}{ }^{-}$assimilation in the canopy influences stemflow concentrations, as $\mathrm{OH}^{-}$is released with $\mathrm{NO}_{3}{ }^{-}$reduction. Furthermore, $\mathrm{NO}_{3}{ }^{-}$is the only compound that occurred in lower concentrations in stemflow than in incident precipitation. This applied to fir in both years of sampling but to spruce only in 2000 when $\mathrm{NO}_{3}{ }^{-}$concentration was lower than in 1999. Two different processes could lead to the negative correlations between lichen cover and $\mathrm{NO}_{3}{ }^{-}$concentration: $\mathrm{NO}_{3}{ }^{-}$assimilation $(i)$ by tree needles or (ii) by epiphytic lichens could control its concentration in stemflow. In the former case, the negative correlations would reflect a dependence of lichen cover on the $\mathrm{NO}_{3}{ }^{-}$concentration in stemflow, whereas in the latter case, $\mathrm{NO}_{3}{ }^{-}$concentration would depend on lichen cover.

$\mathrm{NO}_{3}{ }^{-}$assimilation in needles has been demonstrated for Abies balsamea as well as for Picea rubens (Lang et al. 1976; Boyce et al. 1996). Reduced concentrations of Chl $a$ and $\mathrm{Chl} b$ in Hypogymnia physodes subsequent to incubation 
Table 3. Amounts and element content of incident precipitation.

\begin{tabular}{llll}
\hline & 1999 & 2000 & $p$ \\
\hline $\mathrm{NH}_{4}^{+}\left(\mu \mathrm{mol} \cdot \mathrm{L}^{-1}\right)$ & $62.1 \pm 12.0$ & $67.0 \pm 8.7$ & \\
$\mathrm{NO}_{3}{ }^{-}\left(\mu \mathrm{mol} \cdot \mathrm{L}^{-1}\right)$ & $4.01 \pm 1.08$ & $2.49 \pm 0.66$ & $*$ \\
$\mathrm{P}\left(\mu \mathrm{mol} \cdot \mathrm{L}^{-1}\right)$ & $4.88 \pm 0.59$ & $17.9 \pm 1.5$ & $* * *$ \\
$\mathrm{~S}\left(\mu \mathrm{mol} \cdot \mathrm{L}^{-1}\right)$ & $2.51 \pm 0.40$ & $2.11 \pm 0.30$ & \\
$\mathrm{~K}\left(\mu \mathrm{mol} \cdot \mathrm{L}^{-1}\right)$ & $16.5 \pm 2.7$ & $11.8 \pm 4.0$ & $* * *$ \\
$\mathrm{Na}\left(\mu \mathrm{mol} \cdot \mathrm{L}^{-1}\right)$ & $18.8 \pm 1.2$ & $16.7 \pm 0.7$ & $* * *$ \\
$\mathrm{Ca}\left(\mu \mathrm{mol} \cdot \mathrm{L}^{-1}\right)$ & $3.16 \pm 0.83$ & $4.23 \pm 0.29$ & $* * *$ \\
$\mathrm{Mg}\left(\mu \mathrm{mol} \cdot \mathrm{L}^{-1}\right)$ & $0.69 \pm 0.30$ & $0.39 \pm 0.10$ & \\
$\mathrm{Fe}\left(\mu \mathrm{mol} \cdot \mathrm{L}^{-1}\right)$ & $0.25 \pm 0.06$ & $0.64 \pm 0.06$ & $* * *$ \\
$\mathrm{Mn}\left(\mu \mathrm{mol} \cdot \mathrm{L}^{-1}\right)$ & $0.10 \pm 0.05$ & $0.18 \pm 0.02$ & $* * *$ \\
$\mathrm{Al}\left(\mu \mathrm{mol} \cdot \mathrm{L}^{-1}\right)$ & $4.10 \pm 0.31$ & $4.33 \pm 0.42$ & \\
$\mathrm{Zn}\left(\mu \mathrm{mol} \cdot \mathrm{L}^{-1}\right)$ & $0.13 \pm 0.02$ & $0.45 \pm 0.04$ & $* * *$ \\
$\mathrm{Cu}\left(\mu \mathrm{mol} \cdot \mathrm{L}^{-1}\right)$ & $0.00 \pm 0.00$ & $0.00 \pm 0.00$ & \\
$\mathrm{pH}$ & $4.41 \pm 0.05$ & $4.39 \pm 0.04$ & \\
$\mathrm{Conductivity}\left(\mu \mathrm{S} \cdot \mathrm{cm}^{-1}\right)$ & $20.8 \pm 2.7$ & $21.1 \pm 2.1$ & \\
$\mathrm{Precipitation}\left(\mathrm{mm} \cdot \mathrm{week}^{-1}\right)$ & $36.5 \pm 8.2$ & $28.4 \pm 2.2$ & \\
\hline
\end{tabular}

Note: Data are arithmetic means \pm SE calculated from means of every sample tree over the entire measuring period. Measuring periods were from June to September in 1999 (15 weeks) and 2000 (16 weeks). Asterisks indicate significant differences between years. Statistics: $U$ test, $* p \leq 0.05, * * p \leq 0.01, * * * p \leq 0.001, \mathrm{df}=5$.

with $\mathrm{NO}_{3}{ }^{-}$solution support the assumption that lichen cover was dependent on $\mathrm{NO}_{3}{ }^{-}$concentration. The experimental results with Hypogymnia physodes parallel the results of Boonpragob and Nash (1991), who found negative correlations of the concentration of $\mathrm{NO}_{3}{ }^{-}$leachable from thalli of Ramalina menziesii both with chlorophyll concentrations and with net photosynthesis. Negative correlations of $\mathrm{NO}_{3}{ }^{-}$ concentrations in stemflow with cover of Hypogymnia physodes and with the total of lichen species per sample tree were also found in dieback-affected Picea abies forests of Germany; multiple regression suggested in that case that $\mathrm{NO}_{3}{ }^{-}$had an additional influence besides the $\mathrm{S}$ concentration of stemflow, which was identified as the most important site factor (Hauck and Runge 2002).

Lang et al. (1976) observed a significant uptake of $\mathrm{NO}_{3}{ }^{-}$ from simulated rainwater containing $19 \mu \mathrm{M} \mathrm{NO}{ }_{3}^{-}$and $13 \mu \mathrm{M} \mathrm{NH}_{4}{ }^{+}$in several lichen species that occurred in our plot (i.e., Evernia mesomorpha, Hypogymnia sp., Platismatia glauca, Pseudevernia cladonia, and Usnea sp.). Further, Lang et al. (1980) found an increasing total N concentration in lichens (with green-algal photobiont) with increasing height in the canopy. This could be due to a gradient of $\mathrm{N}$ availability, if $\mathrm{N}$ is constantly taken up from epiphytes, while the rainwater passes the canopy. The latter findings support the hypothesis that epiphytic lichens alter the $\mathrm{NO}_{3}{ }^{-}$concentration in stemflow. Aside from Cladonia coniocraea, Arthonia caesia was the only lichen species occurring on more than $50 \%$ of the sample trees for which no significant correlation with the $\mathrm{NO}_{3}^{-}$concentration in stemflow could be established. The genus Arthonia is known to prefer habitats with low N supply (Wirth 1995). Thus, the lack of correlation could be due to low uptake of $\mathrm{NO}_{3}{ }^{-}$from stemflow, whereas other more nitrophytic species assimilate $\mathrm{NO}_{3}{ }^{-}$in significant amounts. Most Arthonia species live in symbiosis with Trentepohlia, whereas Arthonia caesia belongs to a minority of species with chlorococcoid photobiont. Unfortunately, there is no information available about the specific N requirements of Arthonia caesia.

Since some arguments point to an influence of $\mathrm{NO}_{3}{ }^{-}$assimilation by needles on $\mathrm{NO}_{3}{ }^{-}$concentrations in stemflow, whereas some other arguments indicate an effect of $\mathrm{NO}_{3}{ }^{-}$ assimilation by epiphytic lichens, rates of potential $\mathrm{NO}_{3}{ }^{-}$assimilation for needles and lichens as well as the different biomass of needles and lichens have to be taken into consideration. A rough estimation of the biomass of Hypogymnia physodes for our sample plot yielded $1 \mathrm{~kg}$ of dry weight per fir tree $\left(160 \mathrm{~kg} \cdot \mathrm{ha}^{-1}\right)$ and $250 \mathrm{~g}$ per spruce tree $\left(20 \mathrm{~kg} \cdot \mathrm{ha}^{-1}\right)$. Hypogymnia physodes was the most frequent noncrustose lichen in our plot, and we estimate that about $50 \%$ of the total biomass of epiphytic lichens belonged to this species. This estimation is in line with lichen biomass estimations for Abies balsamea stands in New Hampshire, where epiphyte vegetation was also dominated by Hypogymnia physodes (Lang et al. 1980). The foliar biomass of the phorophytes is supposed to exceed the epiphytic lichen biomass on Whiteface Mountain considerably. In a 115-year-old Picea abies stand of northern Germany, Ellenberg et al. (1986) determined a needle mass of $43 \mathrm{~kg}$ per tree $\left(13 \mathrm{t} \cdot \mathrm{ha}^{-1}\right)$. Provided that this value is transferable to the trees on Whiteface Mountain, this suggests that needle mass is about 20-fold higher than total lichen biomass estimated for Whiteface Mountain. This infers that the rate of $\mathrm{NO}_{3}{ }^{-}$assimilation would have to be much more than 20-fold higher in lichens than in fir and spruce needles, if $\mathrm{NO}_{3}{ }^{-}$assimilation in lichens had a decisive influence on the $\mathrm{NO}_{3}{ }^{-}$concentration in stemflow. However, Lang et al. (1976) found the dry weight related $\mathrm{NO}_{3}{ }^{-}$uptake in the above-mentioned epiphytic lichen species to be only 5-10 times as high as in needles of Abies balsamea. In a Quercus douglasii forest in California, biomass of oak foliage was only 1.6 times higher than that of the fruticose lichen Ramalina menziesii $(6.2$ versus $3.8 \mathrm{~kg}$ per tree; Knops et al. 1996). Despite this, $\mathrm{NO}_{3}{ }^{-}$concentration in the throughfall was not increased under trees, where epiphyte vegetation was removed for the experiment. Although these results are from a different lichen species in a different forest ecosystem, they at least do not support the hypothesis that $\mathrm{NO}_{3}{ }^{-}$assimilation by lichens was decisive for the chemical composition of stemflow on Whiteface Mountain. Therefore, and because of the reduced chlorophyll concentrations following the exposure of Hypogymnia physodes to $\mathrm{NO}_{3}^{-}$solutions, a dependence of $\mathrm{NO}_{3}^{-}$concentrations in stemflow on $\mathrm{NO}_{3}{ }^{-}$assimilation by needles may be more likely. In this case, the different $\mathrm{NO}_{3}^{-}$concentrations on fir and spruce would probably be due to interspecific differences in the rates of aboveground assimilation. However, there are too many estimated parameters in the assessment both of lichen and foliar biomass to draw a definite conclusion. Furthermore, this conclusion has to be regarded with care, as the absolute $\mathrm{NO}_{3}{ }^{-}$concentrations in stemflow are comparably low.

Studies showing detrimental effects of $\mathrm{NO}_{3}^{-}$on lichens are rare, and different species apparently show different responses to comparable $\mathrm{NO}_{3}^{-}$concentrations. While Boonpragob and Nash (1991) found a negative correlation of $\mathrm{NO}_{3}^{-}$supply with chlorophyll content in Ramalina menziesii, Sanchez-Hoyos and Manrique (1995) showed increased concentrations of Chl $a$ and $\mathrm{Chl} b$ in Ramalina 
Table 4. Correlations between cover of lichen species and element concentrations in stemflow.

\begin{tabular}{|c|c|c|c|c|c|}
\hline & Year & $\mathrm{NO}_{3}^{-}$ & $\mathrm{S}$ & $\mathrm{Ca}$ & $\mathrm{Mn}$ \\
\hline \multirow[t]{2}{*}{ Alectoria sarmentosa } & 1999 & $-0.46 * *$ & - & 一 & - \\
\hline & 2000 & $-0.47 * *$ & - & - & 一 \\
\hline \multirow[t]{2}{*}{ Bryoria fuscescens } & 1999 & $-0.38 * *$ & - & - & - \\
\hline & 2000 & -0.40 & - & - & - \\
\hline \multirow[t]{2}{*}{ Cladonia pyxidata s.l. } & 1999 & $-0.36^{*}$ & - & - & 一 \\
\hline & 2000 & $-0.42 * *$ & - & - & - \\
\hline \multirow[t]{2}{*}{ Cladonia squamosa } & 1999 & - & - & - & - \\
\hline & 2000 & $-0.36^{*}$ & - & - & - \\
\hline \multirow[t]{2}{*}{ Evernia mesomorpha } & 1999 & - & - & - & 一 \\
\hline & 2000 & $-0.43 * *$ & - & - & 一 \\
\hline \multirow{2}{*}{ Imshaugia aleurites } & 1999 & $-0.35^{*}$ & - & - & 一 \\
\hline & 2000 & $-0.37 *$ & - & - & - \\
\hline \multirow[t]{2}{*}{ Lecidea nylanderi } & 1999 & $-0.51 *$ & - & - & - \\
\hline & 2000 & $-0.40^{*}$ & - & - & - \\
\hline \multirow[t]{2}{*}{ Pseudevernia cladonia } & 1999 & $-0.52 * * *$ & - & - & - \\
\hline & 2000 & $-0.59 * * *$ & - & - & - \\
\hline \multirow[t]{2}{*}{ Flavopunctelia soredica } & 1999 & $-0.45^{*}$ & - & - & - \\
\hline & 2000 & $-0.42 * *$ & - & $-0.31 *$ & - \\
\hline \multirow[t]{2}{*}{ Hypogymnia physodes } & 1999 & $-0.56 * * *$ & - & - & - \\
\hline & 2000 & $-0.51 * *$ & - & $-0.42 * *$ & 一 \\
\hline \multirow[t]{2}{*}{ Lepraria jackii } & 1999 & $-0.63 * *$ & - & - & - \\
\hline & 2000 & - & - & $-0.51 * *$ & 一 \\
\hline \multirow[t]{2}{*}{ Usnea sp. } & 1999 & $-0.57 * * *$ & - & - & - \\
\hline & 2000 & $-0.54 * * *$ & - & $-0.49 * *$ & - \\
\hline \multirow[t]{2}{*}{ Mycoblastus sanguinarius } & 1999 & $-0.42 * *$ & - & - & - \\
\hline & 2000 & $-0.38^{*}$ & - & $-0.37 *$ & $-0.46 * *$ \\
\hline \multirow[t]{2}{*}{ Platismatia glauca } & 1999 & $-0.36^{*}$ & - & - & - \\
\hline & 2000 & $-0.33^{*}$ & - & - & $-0.34 *$ \\
\hline \multirow[t]{2}{*}{ Parmelia saxatilis } & 1999 & - & - & - & - \\
\hline & 2000 & $-0.35^{*}$ & $-0.37 *$ & $-0.38 *$ & $-0.57 * * *$ \\
\hline \multirow{2}{*}{ Micarea prasina } & 1999 & - & - & - & - \\
\hline & 2000 & - & $-0.35^{*}$ & $-0.36^{*}$ & $-0.57 * * *$ \\
\hline \multirow[t]{2}{*}{ Cladonia coniocraea } & 1999 & - & $-0.36 *$ & - & - \\
\hline & 2000 & - & - & - & - \\
\hline
\end{tabular}

Note: Correlation coefficients calculated from mean concentrations of every sample tree over the entire measuring period. Regression: $y=a /(b x)$. Levels of significance: $* p \leq 0.05, * * p \leq 0.01, * * * p \leq 0.001, \mathrm{df}=38$; -, not significant. Significant correlations not listed in the table: Cladonia coniocraea - Fe (1999), $r=$

$-0.45^{* *}$; Parmelia saxatilis $-\mathrm{Mg}(2000), r=-0.32^{*}$. Species without significant correlation are not listed.

capitata, a rock-dwelling species of N-rich habitats, after spraying with $10 \mathrm{mM} \mathrm{NaNO}_{3}$ for 10 days. The concentration of violaxanthin also increased, increasing resistance against high light influx. Exposure of isolated photobiont cells of several epiphytic lichen species from moderately $\mathrm{N}$-rich habitats (e.g., Anaptychia ciliaris) to $8 \mathrm{mM} \mathrm{Ca}\left(\mathrm{NO}_{3}\right)_{2}$ at $\mathrm{pH} 4$ for $2 \mathrm{~h}$ had no effect on ${ }^{14} \mathrm{C}$ fixation; incubation for 20 days resulted in increased growth rates (Marti 1985). In Cladina stellaris, a lichen species of oligotrophic soils, daily short-term incubation with $10 \mu \mathrm{M} \mathrm{NaNO}$ at $\mathrm{pH} 7.7$ increased the contents of Chl $a$ and $\mathrm{Chl} b$ as well as of total $\mathrm{N}$ (Kauppi 1980).

In Mycoblastus sanguinarius and Parmelia saxatilis, where cover among others decreased with $\mathrm{Mn}$ concentration in stemflow, the latter had the most significant impact on the multiple correlation coefficient. Hauck et al. (2001, 2002a) found negative correlations between the cover of lichen species and the Mn content of Picea abies bark and stemflow. In culture experiments with soredia of Hypogymnia physodes, ambient Mn concentrations reduced their ability to grow, decreased the chlorophyll content, and caused structural damage in algal and fungal cells (Hauck et al. 2002b). Thus, it is conceivable that the correlations found with Mn concentration in stemflow on Whiteface Mountains are causal.

\section{Conclusions}

Similar to montane spruce and spruce-fir forests in Germany (Gliemeroth 1990; Hauck and Runge 1999), epiphytic lichen diversity was higher on dead compared with living trees. Further, epiphytic lichens were significantly more abundant on fir than on spruce, which also agrees with results from central Europe (Gliemeroth 1990; Pfefferkorn 1996) as well as with results from western North America (Jesberger and Sheard 1973; Campbell and Coxson 2001). In contrast with the studies in Germany (Hauck and Runge 2002; Hesse 2002), the $S$ concentration in stemflow did not affect the small-scale distribution of epiphytic lichens on Whiteface Mountains; this can be attributed to the much lower S deposi- 
Table 5. Multiple regression analysis for lichen species cover that correlates with more than one element concentration in stemflow.

\begin{tabular}{|c|c|c|c|c|}
\hline & $\mathrm{df}$ & $R$ & $F, p$ & \\
\hline \multirow[t]{2}{*}{ Flavopunctelia soredica } & 1 & 0.23 & 3.20 & $\mathrm{NO}_{3}^{-}$ \\
\hline & 2 & 0.17 & 1.58 & $\mathrm{NO}_{3}^{-}, \mathrm{Ca}$ \\
\hline \multirow[t]{2}{*}{ Hypogymnia physodes } & 1 & 0.40 & $8.30 * *$ & $\mathrm{NO}_{3}^{-}$ \\
\hline & 2 & 0.43 & $5.30 * *$ & $\mathrm{NO}_{3}^{-}, \mathrm{Ca}$ \\
\hline \multirow[t]{2}{*}{ Usnea sp. } & 1 & 0.36 & $6.81 *$ & $\mathrm{NO}_{3}^{-}$ \\
\hline & 2 & 0.42 & $4.96 *$ & $\mathrm{NO}_{3}^{-}, \mathrm{Ca}$ \\
\hline \multirow[t]{2}{*}{ Platismatia glauca } & 1 & 0.31 & $5.06 *$ & $\mathrm{NO}_{3}^{-}$ \\
\hline & 2 & 0.36 & $3.90 *$ & $\mathrm{NO}_{3}^{-}, \mathrm{Mn}$ \\
\hline \multirow[t]{3}{*}{ Mycoblastus sanguinarius } & 1 & 0.35 & $6.34 *$ & $\mathrm{Mn}$ \\
\hline & 2 & 0.39 & $4.49 *$ & $\mathrm{Mn}, \mathrm{NO}_{3}^{-}$ \\
\hline & 3 & 0.36 & $2.94 *$ & $\mathrm{Mn}, \mathrm{NO}_{3}^{-}, \mathrm{Ca}$ \\
\hline \multirow[t]{5}{*}{ Parmelia saxatilis } & 1 & 0.60 & $22.6 * * *$ & $\mathrm{Mn}$ \\
\hline & 2 & 0.62 & $13.2 * * *$ & $\mathrm{Mn}, \mathrm{Mg}$ \\
\hline & 3 & 0.63 & $9.25 * * *$ & $\mathrm{Mn}, \mathrm{Mg}, \mathrm{NO}_{3}^{-}$ \\
\hline & 4 & 0.61 & $6.77 * * *$ & $\mathrm{Mn}, \mathrm{Mg}, \mathrm{NO}_{3}^{-}, \mathrm{Ca}$ \\
\hline & 5 & 0.60 & $5.25 * * *$ & $\mathrm{Mn}, \mathrm{Mg}, \mathrm{NO}_{3}^{-}, \mathrm{Ca}, \mathrm{S}$ \\
\hline \multirow[t]{3}{*}{ Micarea prasina } & 1 & 0.28 & $4.15^{*}$ & $\mathrm{~S}$ \\
\hline & 2 & 0.32 & 3.14 & $\mathrm{Mn}, \mathrm{Ca}$ \\
\hline & 3 & 0.28 & 2.10 & $\mathrm{Mn}, \mathrm{Ca}, \mathrm{S}$ \\
\hline \multirow[t]{2}{*}{ Cladonia coniocraea } & 1 & 0.37 & $7.34 *$ & $\mathrm{~S}$ \\
\hline & 2 & 0.35 & $3.79 *$ & $\mathrm{~S}, \mathrm{Fe}$ \\
\hline
\end{tabular}

Note: Linear regression with logarithmized data (independent variables: $x=\ln x^{\prime}$; dependent variables: $y=\ln \left(y^{\prime}+1\right)$ ). Data for Cladonia coniocraea from 1999; 2000 otherwise (cf. Table 4). Multiple correlation coefficients $(R)$ were adjusted for number of parameters in the model. Levels of significance: $* p \leq 0.05, * * p \leq 0.01, * * * p \leq 0.001$.

Table 6. Concentrations of chlorophyllous pigments and ergosterol $\left(\mathrm{mg} \cdot \mathrm{g}^{-1}\right)$ in Hypogymnia physodes subsequent to repeated exposure to different $\mathrm{NO}_{3}{ }^{-}$solutions at $\mathrm{pH} 4$ for 1 week.

\begin{tabular}{llllll}
\hline & Control pH 6 & Control pH 4 & $100 \mu \mathrm{M} \mathrm{NO}_{3}^{-}$ & $1 \mathrm{mM} \mathrm{NO}_{3}^{-}$ & $10 \mathrm{mM} \mathrm{NO}_{3}^{-}$ \\
\hline Chl $a$ & $0.79 \pm 0.06 a$ & $0.85 \pm 0.07 a$ & $0.57 \pm 0.04 b$ & $0.56 \pm 0.03 b$ & $0.48 \pm 0.04 b$ \\
Chl $b$ & $0.17 \pm 0.01 a$ & $0.14 \pm 0.02 a$ & $0.09 \pm 0.02 b$ & $0.08 \pm 0.02 b$ & $0.06 \pm 0.01 b$ \\
Phaeo $a$ & $0.86 \pm 0.05 a$ & $0.95 \pm 0.08 a$ & $0.65 \pm 0.06 b$ & $0.60 \pm 0.03 b$ & $0.56 \pm 0.05 b$ \\
Phaeo $b$ & $0.47 \pm 0.03 a$ & $0.52 \pm 0.06 a$ & $0.39 \pm 0.06 a b$ & $0.31 \pm 0.03 b$ & $0.32 \pm 0.04 b$ \\
Ergosterol & $1.29 \pm 0.13 a$ & $1.09 \pm 0.07 a$ & $1.19 \pm 0.06 a$ & $1.19 \pm 0.09 a$ & $1.13 \pm 0.07 a$ \\
\hline
\end{tabular}

Note: Data are arithmetic means \pm SE. Statistics: Duncan's multiple range test, $p \leq 0.05, \mathrm{df}=45$. Within a row, means sharing a common letter do not differ significantly. Concentrations of Chl $a$, Chl $b$, Phaeo $a$, and Phaeo $b$ ) are related to fresh weight of fully water-satured thalli, whereas concentrations of ergosterol refer to dry weight.

tion in upstate New York. Numerous correlations between cover values of lichen species with $\mathrm{NO}_{3}{ }^{-}$concentration in stemflow suggest an interaction between these parameters. However, it cannot be decided whether lichen cover depends on $\mathrm{NO}_{3}{ }^{-}$concentration of stemflow or whether the latter depends on lichen cover. Since our experiments with thallus pieces of Hypogymnia physodes showed that $\mathrm{NO}_{3}{ }^{-}$is capable of reducing the concentrations of $\mathrm{Chl} a$ and $\mathrm{Chl} b$ in this lichen species, an effect of $\mathrm{NO}_{3}{ }^{-}$on cover values may be more probable. In addition, the Mn concentration in stemflow may affect the abundance of selected lichen species.

\section{Acknowledgements}

The first author was supported by grants from the German Exchange Service (DAAD) and the German Na- tional Merit Foundation (Studienstiftung des Deutschen Volkes). The Whiteface Mountain Field Station of the Atmospheric Sciences Research Center, State University of New York at Albany, gave us various kinds of assistance during our field work. Franziska and Sebastian Schmull are thanked for company in the field. We are thankful to Prof. Irwin M. Brodo (Canadian Museum of Nature, Ottawa, Ont.), Dr. Tor Tønsberg (University of Bergen, Norway), and Elisabeth Lay (Boston, Mass.) for their help with identifying critical lichen samples. Marty Dranhoff (University of Pennsylvania, Philadelphia, Pa.) is thanked for his assistance during chemical analyses. Dr. Andrzej Majcherczyk (Institute of Forest Botany, University of Göttingen) gave us the opportunity to conduct the ergosterol analyses. SEM studies were carried out at the Institute of Forest Botany, University of 
Göttingen, under the guidance of Dr. Eberhard Fritz and Konrad Wehr. David Hewitt (Boston) is thanked for proofreading the English.

\section{References}

Boonpragob, K., and Nash, T.H. 1991. Physiological responses of the lichen Ramalina menziesii Tayl. to the Los Angeles urban environment. Environ. Exp. Bot. 31: 229-238.

Boyce, R.L., Friedland, A.J., Chamberlain, C.P., and Poulson, S.R. 1996. Direct canopy nitrogen uptake from ${ }^{15} \mathrm{~N}$-labeled wet deposition by mature red spruce. Can. J. For. Res. 26: 1539-1547.

Brodo, I.M. 1966. Lichen growth and cities: a study on Long Island, New York. Bryologist, 69: 427-449.

Campbell, J., and Coxson, D.S. 2001. Canopy microclimate and arboreal lichen loading in subalpine spruce-fir forest. Can. J. Bot. 79: 537-555

Culberson, C.F., and Ammann, K. 1979. Standardmethode zur Dünnschichtchromatographie von Flechtensubstanzen. Herzogia, 5: 1-24.

Eagar, C., and Adams, B. (Editors). 1993. Ecology and decline of red spruce in the eastern United States. Springer, New York.

Ellenberg, H., Mayer, R., and Schauermann, J. 1986. Ökosystemforschung. Ergebnisse des Sollingprojekts 19661986. Ulmer, Stuttgart.

Esslinger, T.L., and Egan, R.S. 1995. A sixth checklist of the lichen-forming, lichenicolous, and allied fungi of the continental United States and Canada. Bryologist, 98: 467-549.

Gliemeroth, A.K. 1990. Die Flechtenflora kranker Nadelbäume im Nordschwarzwald: Ökologische Untersuchungen zur Differenzierung zwischen Immissionsbelastung und epidemischer Erkrankung. Diss. Bot. 161: 1-148.

Hallingbäck, T., and Kellner, O. 1992. Effects of simulated nitrogen rich and acid rain on the nitrogen-fixing lichen Peltigera aphthosa (L.) Willd. New Phytol. 120: 99-103.

Hauck, M., and Runge, M. 1999. Occurrence of pollution-sensitive epiphytic lichens in woodlands affected by forest decline: a new hypothesis. Flora, 194: 159-168.

Hauck, M., and Runge, M. 2002. Stemflow chemistry and epiphytic lichen diversity in dieback-affected spruce forest of the Harz Mountains, Germany. Flora, 197: 250-261.

Hauck, M., Jung, R., and Runge, M. 2001. Relevance of element content of bark for the distribution of epiphytic lichens in a montane spruce forest affected by forest dieback. Environ. Pollut. 112: 221-227.

Hauck, M., Hesse, V., and Runge, M. 2002a. Correlations between the $\mathrm{Mn} / \mathrm{Ca}$ ratio in stemflow and epiphytic lichen abundance in a dieback-affected spruce forest of the Harz Mountains, Germany. Flora, 197: 361-369.

Hauck, M., Paul, A., Mulack, C., Fritz, E., and Runge, M. $2002 b$. Effects of manganese on the viability of vegetative diaspores of the epiphytic lichen Hypogymnia physodes. Environ. Exp. Bot. 47: 127-142.
Hesse, V. 2002. Epiphytic lichen diversity and its dependence on chemical site factors in differently elevated dieback-affected spruce stands of the Harz Mountains. Diss. Bot. 354: 1-191.

Jesberger, J.A., and Sheard, J.W. 1973. A quantitative study and multivariate analysis of corticolous lichen communities in the southern boreal forest of Sasketchewan. Can. J. Bot. 51: 185-201.

Johnson, A.H. 1987. Untersuchungsstandort: Whiteface Mountain (Adirondacks). Schäden an Rotfichten. In Waldschäden. Ursachenforschung in der Bundesrepublik Deutschland und den Vereinigten Staaten von Amerika. Edited by H.E. Papke, B. Krahl-Urban, K. Peters, and C. Schimansky. KFA, Jülich. pp. 104-105.

Johnson, A.H., Schwartzman, T.N., Battles, J.J., Miller, R., Miller, E.K., Friedland, E.J., and Vann, D.R. 1994. Acid rain and soils of the Adirondacks. II. Evaluation of calcium and aluminum as causes of red spruce decline at Whiteface Mountain, New York. Can. J. For. Res. 64: 654-662.

Kauppi, M. 1980. The influence of nitrogen-rich pollution components on lichens. Acta Univ. Ouluensis Ser. A 101: 1-25.

Knops, J.M.H., Nash, T.H., and Schlesinger, W.H. 1996. The influence of epiphytic lichens on the nutrient cycling of an oak woodland. Ecol. Monogr. 66: 159-179.

Lang, G.E., Reiners, W.A., and Heier, R.K. 1976. Potential alteration of precipitation chemistry by epiphytic lichens. Oecologia, 25: 229-241.

Lang, G.E., Reiners, W.A., and Pike, L.H. 1980. Structure and biomass dynamics of epiphytic lichen communities of balsam fir forests in New Hampshire. Ecology, 61: 541-550.

Lechowicz, M.J. 1982. The effects of simulated acid precipitation on photosynthesis in the caribou lichen Cladina stellaris (Opiz) Brodo. Water Air Soil Pollut. 18: 421-430.

Marti, J. 1985. Die Toxizität von Zink, Schwefel- und Stickstoffverbindungen auf Flechten-Symbionten. Bibl. Lichenol. 21: $1-128$.

Moran, R. 1982. Formulae for determination of chlorophyllous pigments extracted with $N, N$-dimethylformamide. Plant Physiol. 69: $1376-1381$.

Pfefferkorn, V. 1996. Epiphytische Flechtenvereine in Vorarlberg (Österreich) unter besonderer Berücksichtigung der Hemerobie von Waldökosystemen. Vorarlberger Nat. 1: 9-152.

Piervittori, R., Usai, L., Alessio, F., and Maffei, M. 1997. The effect of simulated acid rain on surface morphology and $n$-alkane composition of Pseudevernia furfuracea. Lichenologist, 29: 191-198.

Sanchez-Hoyos, M.A., and Manrique, E. 1995. Effect of nitrate and ammonium ions on the pigment content (xanthophylls, carotenes and chlorophylls) of Ramalina capitata. Lichenologist, 27: 155-160.

Tønsberg, T. 1992. The sorediate and isidiate, corticolous, crustose lichens in Norway. Sommerfeltia, 14: 1-331.

Wirth, V. 1995. Die Flechten Baden-Württembergs. Ulmer, Stuttgart. 
Copyright $\odot 2003$ EBSCO Publishing 